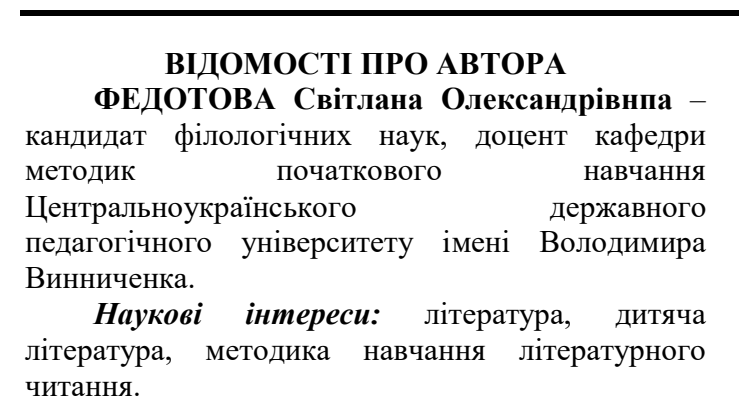

\section{INFORMATION ABOUT AUTHOR}

FEDOTOVA Svitlana Oleksandrivna Candidate of Philology, Assistant Professor of the Department of Methodology of Preschool and Elementary School Education at Volodymyr Vynnychenko Centralukrainian State Pedagogical University.

Circle of scientific interests: literature, literature for children, teaching methodology of literary reading.

Стаття надійшла до редакиії 17.12.2021 p.

UDC -371.134

DOI: 10.36550/2415-7988-2021-1-192-143-147

CHERNIONKOV Yaroslav Olexandrovych Candidate of Pedagogical Sciences, Associate Professor, Department of Linguodidactics and Foreign Languages, Volodymyr Vynnychenko Centralukrainian State Pedagogical University ORCID:https://orcid.org/0000-0001-6598-1581 e-mail: yarcher78professor@gmail.com

\title{
THE ROLE OF PROFILE SCHOOLS IN THE PROCESS OF INDIVIDUALIZATION OF PROFESSIONAL TRAINING OF A FUTURE TEACHER OF FOREIGN LANGUAGES
}

Formulation and justification of the urgency of the problem. In the complex system of modern Ukrainian education, a foreign language occupies a special place due to its social, cognitive and developmental functions as another means of communication, knowledge of the world around us and the expansion of its borders. In the context of this problem, it is worth emphasizing the professional training of future foreign language teachers in specialized schools.

The profile of studying is a way of the organization of differentiated training which provides the expanded, deepened and professionally oriented studying of a cycle of related subjects. The profile of education is determined taking into account the interests and capabilities of students, prospects for further education and professional prospects of student youth; personnel, material and technical, information resources of the school; sociocultural and production infrastructure of the district, region [2].

The profile of studying is a type of differentiation and individualization of education, which allows due to changes in the structure, content and organization of the educational process to take into account the interests, inclinations and abilities of students, their opportunities, to create conditions for high school students in accordance with their educational and professional interests, social and professional self-determination. The main aim of profile-oriented training is to provide conditions for quality education of high school students in accordance with their individual inclinations, opportunities, abilities and needs, to provide professional orientation of students for future activities in demand in the labor market, to establish continuity between general secondary and professional education, spiritual selfimprovement of the individual, the formation of intellectual and cultural potential as the highest value of the nation. The profile school is an institutional form of realization of this purpose [2].

Analysis of recent research and publications. Currently, the problem of specialized training continues to be the focus of domestic scientists. A significant contribution to its solution is made by: G. Ball, V. Guzeyev, V. Kizenko, S. Trubachova, O. Korsakova, N. Shiyan, N. Bibik, O. Bilorykha, N. Vasylenko, V. Volkanova, Y. Gryaznova, N. Dobronravina, O. Kotova, A. Lopukhivska, Zh. Osipenko, S. Sushko, I. Yaremko and many other foreign scientists.

The basis of profile-oriented education in the Austrian primary school is a differentiated approach, which takes into account the age, physical, mental, intellectual characteristics of children and is aimed at the comprehensive development of students and ensuring their professional education. Theoretical principles of learning differentiation have been developed in the works of Austrian and German pedagogues: 
T. Bohl, H. Gudjons, G. Hanisch, W. Isa, K. Clement, G. Neuweg, F. Oswald, L. Paradise, G.-J. Linzer, G. Schwartz, W, Schwendenwein, M. Bönsch and others. The content of profile education of the Austrian primary school is built taking into account the tendency to preserve the general cultural component, which helps the student to optimize learning, which would take into account his/her wishes and aspirations and at the same time maintain the general standard of compulsory education [4, p. 10-15].

The first component of the content of foreign language teacher training is regulatory support. In the United Kingdom, the purpose of training a foreign language teacher is specified in a United Kingdom Government circular № 5/99 of the Ministry of Education and Employment in 1999. The document consists of three sections: 1) teaching methods, educational planning and classroom guidance; 2) monitoring, evaluation of students' activities in the learning process, the ability to keep school records, follow the rules of reporting, responsibility for the educational process; 3 ) other professional requirements. In addition, the training of foreign language teachers in the UK is based on national and regional (England, Wales and Northern Ireland) professional standards approved from 2007 to 2009, which consist of the following elements: professional knowledge, skills, qualities or values [1, p. 68$100]$.

If a language program in elementary school is to enjoy continued success, it must be part of a comprehensive, long-range plan for language instruction in the district that includes foreign language programs in middle and high schools. Well-qualified teachers who receive regular professional development. Foreign language teachers in elementary grades should have native or near native proficiency in the target language, be certified as elementary teachers, and have a background in child language acquisition and foreign language teaching methods.

Profile-oriented studying of a foreign language is a purposeful training of students for further educational and / or professional activities related to the use of a foreign language as an object of future (professional) activity or as a means of professional communication. Today, school profiling is one of the important directions of modernization of Ukrainian general education. The introduction of specialized profile education in senior (10-11) grades of secondary schools is due to current trends in national education, social order to school by the state and society, socio-economic and sociocultural development of Ukraine, as well as analysis of the positive experience of foreign countries' school education. The laws of Ukraine «On Education», «On General Secondary Education», the Concept of profile education in high school, the State standard of basic and complete general secondary education and other legal documents are the theoretical basis for the introduction of profile education [3, p. 4].

Recently, the organization of profileoriented training has attracted the attention of many scientists. In particular, the issues of professional self-determination and professional orientation were studied by such Ukrainian and Russian scientists as O. Vitkovska, O. Deshchenko; the choice of profile was studied by N. Bibik, N. Ladnushkina, L. Lipova; I. Artyukhov, E. Moroz, O. Petunin, L. Serebrennikov, and others. analyzed the content of pre-professional training in their works. Theoretical-methodological principles of profile-orientedd training were developed by N. Aniskina, N. Desyatnychenko, V. Kyzenko, V. Krupnyk, E. Polat, N. Shiyan and others. The psychological foundations of specialized training were determined by $\mathrm{P}$. Lerner, G. Loginova, V. Ognevyuk, Y. Rassadkin, L. Filatova, N. Kharitonov and others. N. Aniskina, B. Bilyak, S. Volyanska, S. Kovpak, G. Moskalyk, E. Ogorodnikov, S. Chyzh, and others studied the organizational aspects of school profiling. Problems and prospects for the development of specialized education in Ukraine and Russia were studied by V. Bolotov, M. Vidnichuk, G. Memega, T. Remekh, I. Shcherbo, and others. The structure, features, problems and prospects of the rural profile school were determined by A. Bethlehem, G. Ivanyuk, A. Ostapenko and others. Important conclusions about specialized training can be found in the dissertation research of E. Bogomolova, E. Bolotov, N. Grivenko, I. Danilina, T. Zakharova, V. Lyulka, S. Mazurenko, G. Melnyk, L. Novikova, O. Pinaeva, A. Samodrina.

The purpose of the article is: to outline the significance, priorities and problems of the introduction of specialized education in the system of general secondary education; to determine the conceptual role and qualitative impact of profile schools in the process of post university period; to analyze the essence of the concepts of «profile schoo»l, «profile school professional training»; to investigate theoretical and practical conceptual foundations of the studied theme in the conditions of pre-high school period - high school period -post-high school period.

The main material of the study. At the university level, foreign language professors are 
expected to meet the same criteria as most English literature professors. This means that they are not only fluent in a foreign language but have also proved themselves as an expert on a particular aspect related to a foreign language's literature or culture. As a foreign language professor at the university level, one may be grouped under a specific department related to Foreign Languages or Modern Languages; or belong to a sub-category of departments, such as the Department of German Studies. In addition to their work in the classroom, professors typically supervise graduate students completing their master's degrees and $\mathrm{PhDs}$ in a foreign language or literature field.

Realization of the aim and tasks of profile training is carried out on the basis of the principles which are caused by the personoriented, competence paradigm of education and education and reflect specificity of profile training.

The principle of social balance. It involves the coordination of three positions: the possibilities of educational services, labor market demands and social expectations of school graduates.

The principle of continuity. Provides for the relationship between pre-professional training, profile-oriented studying and professional training.

The principle of flexibility. It consists in providing opportunities and conditions for changing the profile of education, content and forms of organization of profile education, including distance, wide choice of content of educational programs and opportunities for its correction.

The principle of variability. It consists of multilevel curricula, educational programs, educational content, use of various technologies, giving students the opportunity to choose subjects (courses) that are freely studied, change activities, use an integrative approach in the study of compulsory subjects.

The principle of diagnostic and prognostic feasibility. It is to identify the abilities of students for a reasonable orientation to the profile of study and further professional selfdetermination.

The principle of differentiation. It is to provide conditions for students to voluntarily choose a profile of education, based on their cognitive interests, abilities, learning outcomes and professional intentions.

The principle of individualization. Provides for the consideration of individual characteristics of the individual to achieve the goal, which serves as a basis for the implementation of personality-oriented learning in the profile school [2].

The principle of social balance. We mean that it is necessary to develop a system in which there will be a close connection between all elements of profile training: Native school studying (school leaver) $\rightarrow$ High School training (future foreign language teacher) $\rightarrow$ Native school work (Foreign language teacher). The school-leaver must know clearly about the working conditions, living conditions, salary, when he returns to work in his native school to the place allotted to him in advance.

The principle of continuity. Our understanding of this system can be seen in such a way:

1. Pre-school education - Initial study of a foreign language: alphabet, songs, game activity;

2. 1 grade (New Ukrainian School) First-grade school, one-on-one group lessons;

3. 2-4 grades (New Ukrainian School) Individual group classes, different research circle activities, increasing the number of hours for studying English;

4. 5-9 grades (New Ukrainian School) Increasing the number of hours for learning a foreign language; second language (categorically not Russian); different research circle work; individual classes, various «English Speaking Clubs!, partial profiling;

5. 10-12 grades (Concept of Profile Education at Senior School) - Full Profiling (increasing the number of hours for foreign language courses; individual classes on the selected profile, research circles work, various communicational clubs, preparation for the B1 exam at the IEE);

6. University / bachelor degree (New Concept of Developing English Language at Universities) - Increasing hours and changing the content of language subjects, exams to confirm the level of English at B2, a mandatory requirement that a bachelor's student, regardless of specialty, must acquire a foreign language at B1 + level if he/she wants to get a diploma, the Unified Entrance Exam (UEE) - i.e. Independent External Evaluation (IEE) in Foreign Language to Master's Degree;

7. University / magistracy (New Concept of Developing English Language at Universities) - the Unified Entrance Exam (UEE) - i.e. Independent External Evaluation (IEE) in Foreign Language to Master's Degree; scientific work in a foreign language as a component of the Unified State Qualification Exam (USQE) for most specialties, passed / failed; recommend that universities assess their English proficiency during masters certification;

8. Postgraduate education (improvement 
work in a profile school) - creating of material, technical, methodical and didactic base of the model; working -about the history and culture of the countries in which the language is prevalent; organizing special events that help their pupils gain a better grasp of the language and culture, such as hosting language dinners, assigning independent projects, creating cultural displays, and arranging dance/song performances; providing individual support; conducting classes, open sessions and workshop-type classes [5, c. 184-187].

The principle of flexibility. This means that the student during the bachelor's degree must be provided with conditions for the so-called «learning mobility», according to which he can change his profile, or study for several at once. The student also has the right to freely choose or change a profile for a master's degree. Also an important point is the choice of forms of organization of profile-oriented training and types of training. It is implied that the student can choose full-time or part-time forms, individual, distance or mixed

The principle of variability. The first attempt in this direction is the system of elective disciplines, which was introduced a few years ago, but will work efficiently and effectively only from the 2020-2021 academic year. When students have the right to choose disciplines they like and several levels of programs, methods, technologies, plans, they have more opportunities to obtain a higher level of diverse education in their field.

The principle of diagnostic and prognostic feasibility. This principle is aimed at the close work of the teaching staff of the school and the teaching staff of the High school. For future foreign language teachers (still pupils) the deanery of the faculty organizes annual meetings, «Open Days», «several days of internships» for faster and better orientation and painless future adaptation in the educational environment of the faculty and High school in general.

The principle of differentiation and individualization. At the end of the 9th grade, students choose the profile of their future profession and the trajectory of studying. All further education is aimed at revealing individual features and characteristics in the process of profile personality-oriented education, so that after graduation the future foreign language teacher could enter the planned and dream faculty.

Conclusions and prospects for further researches of directions. The model of profileoriented studying in foreign language has not yet been implemented in the practice of the school in full. Teachers work to create a logistical, methodological and didactic base of the model. Work plans of circles, mini-textbooks, electronic manuals, other materials are developed.

Therefore, the integration of profile oriented studying will maximize the continuous studying of both students and teachers and achieve high performance. We understand that our observation is only part of the research program we have created for this issue. Further studies we see in the analysis of the practicalmethodical system of profile-oriented studying of future teacher of foreign languages.

\section{СПИСОК ДЖЕРЕЛ}

1. Гарбуза Т. В. Професійна підготовка майбутніх учителів іноземної мови в системі дистанційного навчання університетів Великої Британії / Гарбуза Тетяна Віталіївна / Дисертація канд. пед. наук. 13.00.04 теорія та методика професійної освіти, 2015. $236 \mathrm{c}$.

2. Концепція профільного навчання у старшій школі [Electron resource] Available from: http://vokrda.kuprda.gov.ua/info/page/6834 (дата звернення: 15.01.2021).

3. Полонська Т. К. Профільне навчання іноземної мови учнів старшої школи : метод. рек. / Т. К. Полонська. К. : Педагогічна думка, 2014. $80 \mathrm{c}$.

4. Фаннінгер Л. П. Особливості профільного навчання в основній школі Австрії / Фаннінгер Людмила Павлівна / Автореф...дис.канд.пед.наук. 13.00.04. Теорія та методика професійної освіти, 2008. 22 c.

5. Chernionkov Yaroslav. Modern understanding of foreign language teacher training system / Yaroslav Chernionkov / Academic notes / Ed. Board: V. F. Cherkasov, V. V. Radul, N. S. Savchenko, etc. Edition 185. Series: Pedagogical Sciences. - Kropyvnytskyi: EPC of Volodymyr Vynnychenko Centralukrainian State Pedagogical University, 2020. P. 184-187.

\section{REFERENCES.}

1. Harbuza, T. V. (2015). Profesiina pidhotovka maibutnikh uchyteliv inozemnoi movy $v$ systemi dystantsiinoho navchannia universytetiv Velykoi Brytanii. [Professional training of future foreign language teachers in the distance learning system of British universities]. Zhytomyr.

2. Kontseptsiia profilnoho navchannia u starshii shkoli. (2013). [The concept of specialized education in high school]. Kyiv.

3. Polonska, T. K. (2014). Profilne navchannia inozemnoi movy uchniv starshoi shkoly. [Profile foreign language teaching of high school students: manual]. Kyiv.

4. Fanninher, L. P. (2008). Osoblyvosti profilnoho navchannia $v$ osnovnii shkoli Avstrii. [Features of specialized education in primary school in Austria]. Ternopil.

5. Chernionkov Yaroslav. (2020). Suchasne rozuminnia systemy pidhotovky vchyteliv inozemnykh mov. [Modern understanding of foreign language teacher training system]. Kropyvnytskyi. 


\footnotetext{
ІНФОРМАЦІЯ ПРО АВТОРА

ЧЕРНЬОНКОВ Ярослав Олександрович кандидат педагогічних наук, доцент кафедри лінгводидактики та іноземних мов Центральноукраїнського державного педагогічного університету імені Володимира Винниченка.

Наукові інтереси: процеси індивідуалізації підготовки майбутніх учителів іноземних мов; методи навчання іноземних мов на нелінгвістичних факультетах; формування майбутніх вчителів іноземних мов.
}

INFORMATION ABOUT THE AUTHOR

CHERNIONKOV Yaroslav Olexandrovych Ph.D, Candidate of Pedagogical Sciences, Associate Professor of the Department of Linguodidactics and Foreign Languages Volodymyr Vynnychenko Centralukrainian State Pedagogical University.

Circle of scientific interests: processes of individualization of training future teachers of foreign languages; methods of teaching foreign languages at the non-linguistic faculties; formation of future teachers of foreign languages.

Стаття надійшла до редакиіï 20.01.2021 р.

ШЕВЧЕНКО Світлана Миколаївна кандидат педагогічних наук, старший науковий співробітник відділу історії та філософії освіти Інституту педагогіки НАПН України ORCID:https://orcid.org/0000-0002-0432-8893 e-mail: shevchenko_s_n@ukr.net

\section{«ПОЛОЖЕННЯ ПРО НАВЧАЛЬНО-РЕАБІЛІТАЦЙНИЙ ЦЕНТР»- ЯК ОДИН ІЗ ЧИННИКІВ РЕФОРМУВАННЯ ШКІЛЬНОЇ ОСВІТИ ДЛЯ ДІТЕЙ З ОСОБЛИВИМИ ПОТРЕБАМИ У 2011- 2017 РОКИ}

\begin{abstract}
Постановка та обгрунтування актуальності проблеми. Нині інтеграція України до європейського, економічного, культурного й освітнього простору вимагає розв'язання низки проблем у навчальновиховному процесі дітей 3 особливими потребами, які відображаються на духовному і моральному рівнях. У час суспільного розвитку й перехід до ринководемократичних відносин України суспільство вимагає від державних органів управління освітою, педагогічної науки, нових, нестандартних підходів у розв'язанні проблем навчання, виховання, оздоровлення, соціального захисту та матеріального забезпечення дітей з особливими потребами $[9$, c. 12].

Робота 3 дітьми з особливими потребами $\epsilon$ одним із важливих і пріоритетних напрямів спеціальної педагогіки, в основі якої правові чинники соціального захисту та підтримки цієї категорії дітей. На всіх етапах розвитку суспільства шкільна освіта для дітей 3 особливими потребами займала важливе місце у становленні педагогічної науки. Вона $\epsilon$ складова частина процесу вдосконалення системи спеціальної освіти. На сьогоднішній день особливий інтерес в історичному аспекті викликають дослідження діяльності навчальнореабілітаційних центрів (далі - НРЦ) як нового типу начальних закладів для дітей 3
\end{abstract}

особливими потребами. Аналіз історичної ретроспективи НРЦ допоможе вирішити питання взаємодії теорії i практики, простежити в якій мірі отримали практичне розв`язання актуальні проблеми шкільної освіти навчання i виховання дітей 3 особливими потребами. А також показати, що нового, цінного було вперше зроблено для розвитку шкільної освіти для дітей 3 особливими потребами в досліджуваний період. Обгрунтування понятійнотермінологічного апарату допоможе усвідомити роль НРЦ у вдосконаленні системи суспільного виховання та навчання дітей з особливими потребами.

Аналіз останніх досліджень i публікацій. Вітчизняні сурдопедагогипрактики висловили низку цінних ідей i теоретичних положень в монографіях i навчальних посібниках А. Басової, В. Бондаря, В. Демиденко, О. Дьячкова, А. Добрової, С. Сгорова, I. Срьоменко, В. Покиданов, В. Слюсаренко, М. Ярмаченка та ін. Про теоретичні й методичні основи діяльності інтернатних закладів розповідається у роботах зарубіжних авторів В. Афанасьєв, Г. Заликін, В. Сфремова, Е. Костяшкін, М.Тайчинов та ін. У дисертаційнихих роботах представлено окремі аспекти розвитку інтернатних закладів та удосконалення навчання й виховання дітей в цих закладах 